\title{
SPECIES DELIMITATION IN GERANIUM SECT. BATRACHIOIDEA: MORPHOLOGICAL AND MOLECULAR
}

\author{
S. Esfandani Bozchaloyi ${ }^{* 1}$, M. SHEIDAI ${ }^{1}$ \\ M. Keshavarzi ${ }^{2}$ and Z. Noormohammadi ${ }^{3}$ \\ ${ }^{1}$ Department of Plant Sciences, Faculty of Biological Sciences, Shahid Beheshti University, Tehran, \\ Iran; E-mails: *somayehesfand@yahoo.com,msheidai@yahoo.com,msheidai@sbu.ac.ir \\ ${ }^{2}$ Department of Plant Sciences, Faculty of Biological Science, Alzahra University, Tehran, Iran; \\ E-mail: neshat112000@yahoo.com \\ ${ }^{3}$ Department of Biology, Science and Research Branch, Islamic Azad University, Tehran, Iran; \\ E-mail:marjannm@yahoo.com
}

(Received 7 April, 2017; Accepted 20 June, 2017)

Geranium subg. Robertium (Geraniaceae) comprises eight sections, of which sect. Batrachioidea contains four species centred in Eurasia, Mediterranean region and the Himalaya Mountains. Three species of Geranium pusillum, G. molle and G. pyrenaicum occur in Iran show some degree of morphological overlaps that make the species delimitation difficult. Moreover, hybrids are known to be formed between these species elsewhere. Till present time, there has been no detailed information available on molecular phylogeny and genetic structure of these species in the country. Therefore, the present study was conducted with the aim to investigate species delimitation by both morphological and molecular data and to reveal genetic diversity and population structure in these three Geranium species. For this study, 216 randomly collected plants from 30 geographical populations in three Geranium species were used. We encountered extensive within species genetic and morphological diversity. ISSR molecular markers could not delimit the studied species. STRUCTURE analysis revealed the occurrence gene flow between these species. The Mantel test showed no correlation between genetic distance and geographical distance of the populations studied. Statistical analysis showed no significant difference between ITS and $r b c$ L sequences and phylogenetic tree was constructed based on combined data set which separated outgroups from the studied species. Genetic affinity of the studied species has been discussed.

Key words: Geranium, ISSR, network, population structure, species delimitation

\section{INTRODUCTION}

Geranium L. is a cosmopolitan genus, with about 420 species being recognized in three subgenera: Eroideae (Picard) Yeo, Robertium (Picard) Bouy and Geranium, distinguished by fruit dispersal and eighteen sections (Aedo et al. 1998a). A brief history of the generic delimitation and infra-generic classifica- 
tion, and a complete description of the genus are provided by Aedo (1996). Latter on Aedo et al. (1998a, b), provided an identification key for subgenera and their relative sections.

Some of the most interesting health benefits of Geranium include its ability to reduce inflammation, improve kidney health, relieve pain, lower stress levels, strengthen the immune system, and ease digestion. The essential oil of Geranium flowers is also highly sought after for its health benefits. The aerial parts of some Geranium species have been used as a tonic, diuretic, antidiabetic, antidiarrheal and antihemorrhoidal and also as a remedy to cure gastric disorders and wounds (Baytop 1999).

Geranium subg. Robertium (Geraniaceae) comprises eight sections, of which sect. Batrachioidea W. D. J. Kotch contains four species that are centred in Eurasia, Mediterranean region and the Himalayas.

Most Geranium species are herbaceous perennial plants with highly divided palmately lobed or cleft leaves, horizontal rhizomes. However, some species in subg. Robertium and Geranium are annuals, while sect. Batrachioidea has one perennials and three annual species. G. pyrenaicum Burm. f. is a perennial species with vertical, napiform rhizome. All species of this section have deeply palmatifid leaves. The most distinctive characters for Geranium sect. Batrachioidea are its obdeltate leaf segments, short petal claws, and chromosome number of $2 n=26$. The chromosome number is especially relevant as a derived character, as it has not been found in any other section of subg. Robertium (Aedo et al. 1998b).

There have been reports on the occurrence of interspecific hybridisation within Geranium. For example, hybrids do occur between the species of sect. Anemonifolia, Batrachioidea, Lucida, Ruberta and Unguiculata (Van Loon 1984, Yeo 1987), but no data are available for sect. Divaricata, Polyantha, and Trilopha.

In sect. Batrachioidea, three hybrids have been described as $G . \times$ oenense (G. molle $\times$ G. pusillum); G. $\times$ luganense (G. molle $\times$ G. pyrenacium); and G. $\times$ hybridum (G. pusillum $\times$ G. pyrenacium) (Van Loon 1984). As the studied species in this work show geographical distribution overlaps, there is a possibility of encountering hybrid zone and inter-specific hybrids.

Three species of Geranium pusillum L., G. molle L., and G. pyrenaicum occur in Iran and show some degree of morphological overlaps. Therefore, their taxonomic delimitation becomes somewhat problematic particularly in areas that may grow in vicinity.

Plant species delimitation and interspecific genetic diversity are two important areas of investigation in phylogenetic systematics, evolution, biogeography and biodiversity studies. Data obtained can help to understand the patterns and mechanisms of speciation and hybridisation (Minaeifar et al. 2016, Safaei et al. 2016). They can reveal the pattern of gene flow between 
closely related phylogenetic species versus isolation by distance and identify the evolutionary process by which new biological species arise (Freeland et al. 2011, Sheidai et al. 2016). Species delimitation is a difficult task particularly in the species with cross-pollination breeding system that tend to form frequent interspecific hybrids (Sheidai et al. 2016).

Different molecular markers have been used in species delimitation and genetic diversity studies. These include both neutral multilocus markers (e.g., SSRs (simple sequence repeats), ISSRs (inter-simple sequence repeats) and AFLPs (amplified fragments length polymorphism)), etc. as well as DNA sequences (e.g., ITS (internal transcribed sequences) of ribosomal DNA and chloroplast DNA) (see for example, Sheidai et al. 2012, 2013, Koohdar et al. 2015, Mosaferi et al. 2015, 2016, Minaeifar et al. 2016, Safaei et al. 2016).

We used both ISSRs as well as ITS and $r b c$ L gene of cp-DNA to carry out species delimitation. Similarly, we used ISSRs to investigate population genetic diversity and structure. For this purpose we collected plants of Geranium pusillum, G. molle and G. pyrenaicum from the areas they grow and the areas of overlap and delimit these three species and identify potential hybrids if at all occurring.

\section{MATERIALS AND METHODS}

\section{Plant materials}

In present study 216 plant samples were collected from 30 geographical populations. Different references were used for the correct identification of species (G. molle, G. pyrenaicum and G. pusillum) (Aedo et al. 1998b, Davis 1965, Janighorban 2009, Schönbeck-Temesy 1970, Zohary 1972). Details of sampling sites are mentioned (Table 1 and Fig. 1). Voucher specimens are deposited in Herbarium of Shahid Beheshti University (HSBU).

Morphological studies - In total 80 morphological characters (42 qualitative, 38 quantitative) were studied. Five plant specimens were randomly studied or morphological analyses (Table 2).

DNA extraction and ISSR assay - Fresh leaves were used randomly from 5-10 plants in each of the studied populations. These were dried by silica gel powder. CTAB activated charcoal protocol was used to extract genomic DNA (Sheidai et al. 2013). The quality of extracted DNA was examined by running on $0.8 \%$ agarose gel. Ten ISSR primers; (AGC) 5GT, (CA) 7GT, (AGC) 5GG, UBC 810, (CA) 7AT, (GA) 9C, UBC 807, UBC 811, (GA) 9T and (GT) 7CA commercialised by UBC (the University of British Columbia) were used. PCR reactions were carried in a $25 \mu \mathrm{l}$ volume containing $10 \mathrm{mM}$ Tris- $\mathrm{HCl}$ buffer at $\mathrm{pH} 8 ; 50 \mathrm{mM} \mathrm{KCl} ; 1.5 \mathrm{mM} \mathrm{MgCl}{ }_{2} ; 0.2 \mathrm{mM}$ of each dNTP (Bioron, Ger- 
Table 1

Location and herbarium accession numbers of the studied populations of G. molle L., G. pyrenaicum Burm. f. and G. pusillum L. collected by Esfandani in Iran. Po = population, Alt. = altitude

\begin{tabular}{|c|c|c|c|c|c|}
\hline Po & Locality & Latitude & Longitude & $\begin{array}{l}\text { Alt. } \\
(\mathrm{m})\end{array}$ & $\begin{array}{l}\text { Voucher } \\
\text { number }\end{array}$ \\
\hline \multicolumn{6}{|c|}{ G. molle L. } \\
\hline 1 & $\begin{array}{l}\text { Mazandaran, Siahbisheh to } \\
\text { Chalus }\end{array}$ & $36^{\circ} 14^{\prime} 14^{\prime \prime}$ & $51^{\circ} 18^{\prime} 07^{\prime \prime}$ & 1807 & HSBU 201648 \\
\hline 2 & Guilan, Bandar Anzali, road side & $37^{\circ} 27^{\prime} 48^{\prime \prime}$ & $49^{\circ} 33^{\prime} 20^{\prime \prime}$ & -23 & HSBU 201649 \\
\hline 3 & Mazandaran, Amol & $36^{\circ} 27^{\prime} 42^{\prime \prime}$ & $52^{\circ} 21^{\prime} 00^{\prime \prime}$ & 103 & HSBU 201650 \\
\hline 4 & Mazandaran, Nur & $36^{\circ} 34^{\prime} 24^{\prime \prime}$ & $52^{\circ} 00^{\prime} 50^{\prime \prime}$ & -20 & HSBU 201651 \\
\hline 5 & $\begin{array}{l}\text { Mazandaran, Noshahr, Khey- } \\
\text { rudkenar Forest }\end{array}$ & $36^{\circ} 38^{\prime} 05^{\prime \prime}$ & $51^{\circ} 29^{\prime} 05^{\prime \prime}$ & -16 & HSBU 201652 \\
\hline 6 & Mazandaran, Babol & $36^{\circ} 20^{\prime} 53^{\prime \prime}$ & $52^{\circ} 30^{\prime} 20^{\prime \prime}$ & 606 & HSBU 201653 \\
\hline 7 & Guilan, Golerodbar & $37^{\circ} 09^{\prime} 55^{\prime \prime}$ & $49^{\circ} 55^{\prime} 49^{\prime \prime}$ & 15 & HSBU 201654 \\
\hline 8 & Mazandaran, Noshahr & $36^{\circ} 35^{\prime} 04^{\prime \prime}$ & $51^{\circ} 48^{\prime} 24^{\prime \prime}$ & -29 & HSBU 201655 \\
\hline 9 & Mazandaran, Shirgah & $36^{\circ} 14^{\prime} 47^{\prime \prime}$ & $52^{\circ} 54^{\prime} 20^{\prime \prime}$ & 466 & HSBU 201656 \\
\hline 10 & Mazandaran, Sang Deh Forest & $36^{\circ} 01^{\prime} 11^{\prime \prime}$ & $53^{\circ} 13^{\prime} 26^{\prime \prime}$ & 1720 & HSBU 201657 \\
\hline 11 & Guilan, Siahkal, Ezbaram & $37^{\circ} 07^{\prime} 48^{\prime \prime}$ & $49^{\circ} 54^{\prime} 04^{\prime \prime}$ & 63 & HSBU 201658 \\
\hline 12 & Guilan, Siahkal, Ezbaram & $37^{\circ} 07^{\prime} 08^{\prime \prime}$ & $49^{\circ} 54^{\prime} 11^{\prime \prime}$ & 165 & HSBU 201659 \\
\hline 13 & Mazandaran, Qaemshahr & $36^{\circ} 28^{\prime} 17^{\prime \prime}$ & $52^{\circ} 51^{\prime} 10^{\prime \prime}$ & 51 & HSBU 201660 \\
\hline 14 & Golestan, Ramian & $37^{\circ} 0^{\prime} 8.23^{\prime \prime}$ & $\begin{array}{l}55^{\circ} 8^{\prime} \\
50.73^{\prime \prime}\end{array}$ & 1320 & HSBU 201661 \\
\hline 15 & East Azerbaijan kaleybar & $38^{\circ} 52.393^{\prime}$ & $47^{\circ} 25.92^{\prime}$ & 1133 & HSBU 201662 \\
\hline 16 & East Azerbaijan kaleybar & $38^{\circ} 52.393^{\prime}$ & $47^{\circ} 25.92^{\prime}$ & 1133 & HSBU 201663 \\
\hline 17 & $\begin{array}{l}\text { Mazandaran, Tonekabon, } \\
\text { Shirod }\end{array}$ & $37^{\circ} 0^{\prime} 8.23^{\prime \prime}$ & $\begin{array}{l}55^{\circ} 8^{\prime} \\
50.73^{\prime \prime}\end{array}$ & -16 & HSBU 201664 \\
\hline 18 & Mazandaran, Tuska Cheshmeh & $36^{\circ} 38.952^{\prime}$ & $53^{\circ} 48.569^{\prime}$ & 1427 & HSBU 201665 \\
\hline \multicolumn{6}{|c|}{ G. pyrenaicum Burm. f. } \\
\hline 19 & Mazandaran, Sang Deh Forest & $36^{\circ} 01^{\prime} 11^{\prime \prime}$ & $53^{\circ} 13^{\prime} 26^{\prime \prime}$ & 1720 & HSBU 201666 \\
\hline 20 & Mazandaran, Veresk Bridge & $35^{\circ} 54^{\prime} 12^{\prime \prime}$ & $52^{\circ} 59^{\prime} 27^{\prime \prime}$ & 1579 & HSBU 201667 \\
\hline 21 & E Azerbaijan kaleybar & $38^{\circ} 52.393^{\prime}$ & $47^{\circ} 25.92^{\prime}$ & 1144 & HSBU 201668 \\
\hline 22 & $\begin{array}{l}\text { E Azerbaijan kaleybar, Chesh- } \\
\text { mealiakbar }\end{array}$ & $38^{\circ} 52.393^{\prime}$ & $47^{\circ} 25.92^{\prime}$ & 1133 & HSBU 201669 \\
\hline 23 & E Azerbaijan kaleybar, Shojabad & $38^{\circ} 52.393^{\prime}$ & $47^{\circ} 25.92^{\prime}$ & 1137 & HSBU 201670 \\
\hline 24 & E Azerbaijan kaleybar, road side & $38^{\circ} 52.393^{\prime}$ & $47^{\circ} 25.92^{\prime}$ & 1122 & HSBU 201671 \\
\hline 25 & E Azerbaijan, Babak fort & $38^{\circ} 51^{\prime} 51^{\prime \prime}$ & $47^{\circ} 02^{\prime} 28^{\prime \prime}$ & 1155 & HSBU 201672 \\
\hline
\end{tabular}


Table 1 (continued)

\begin{tabular}{llcrcc}
\hline Po & Locality & Latitude & Longitude & $\begin{array}{c}\text { Alt. } \\
(\mathrm{m})\end{array}$ & $\begin{array}{c}\text { Voucher } \\
\text { number }\end{array}$ \\
\hline \multicolumn{7}{l}{} & G. pusillum L. & & & \\
\hline 26 & E Azerbaijan kaleybar & $38^{\circ} 52.393^{\prime}$ & $47^{\circ} 23.92^{\prime}$ & 1144 & HSBU 201673 \\
27 & Mazandaran, Sang Deh Forest & $36^{\circ} 01^{\prime} 11^{\prime \prime}$ & $53^{\circ} 13^{\prime} 26^{\prime \prime}$ & 1720 & HSBU 201674 \\
28 & $\begin{array}{l}\text { E Azerbaijan kaleybar, Chesh- } \\
\text { mealiakbar }\end{array}$ & $38^{\circ} 52.393^{\prime}$ & $47^{\circ} 25.92^{\prime}$ & 1133 & HSBU 201675 \\
29 & E Azerbaijan kaleybar, Shojabad & $38^{\circ} 52.393^{\prime}$ & $47^{\circ} 25.92^{\prime}$ & 1137 & HSBU 201676 \\
30 & E Azerbaijan kaleybar, road side & $38^{\circ} 52.393^{\prime}$ & $47^{\circ} 25.92^{\prime}$ & 1122 & HSBU 201677 \\
\hline
\end{tabular}

many); $0.2 \mu \mathrm{M}$ of a single primer; 20 ng genomic DNA and $3 \mathrm{U}$ of TaqDNA polymerase (Bioron, Germany). The amplifications' reactions were performed in Techne thermocycler (Germany) with the following program: 5 min initial denaturation step $94^{\circ} \mathrm{C}$, followed by 40 cycles of $1 \mathrm{~min}$ at $94^{\circ} \mathrm{C} ; 1 \mathrm{~min}$ at $52-57$ ${ }^{\circ} \mathrm{C}$ and $2 \mathrm{~min}$ at $72{ }^{\circ} \mathrm{C}$. The reaction was completed by final extension step of

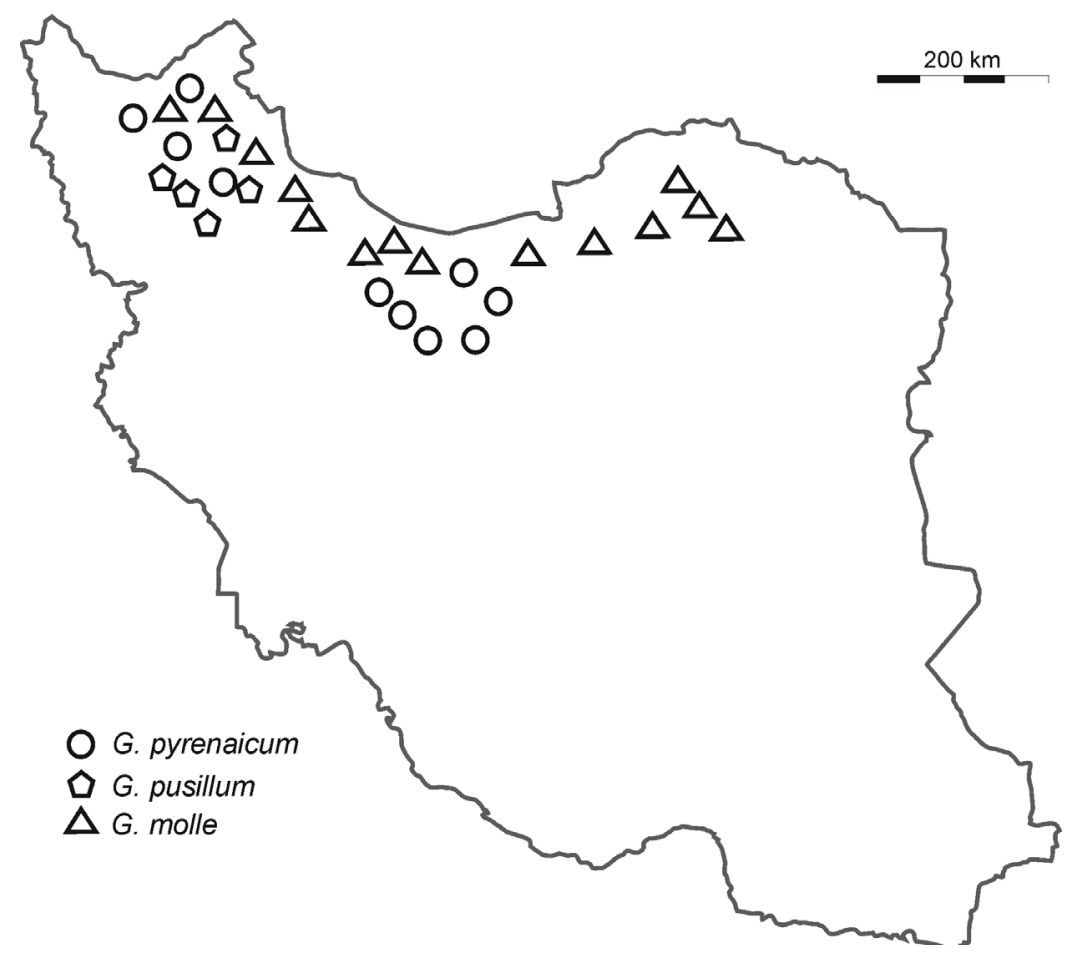

Fig. 1. Distribution map of the populations studied 
Table 2

Evaluated morphological characters

\begin{tabular}{|c|c|c|c|}
\hline No & Character & No & Character \\
\hline 1 & Plant height (mm) & 33 & Peduncle length (mm) \\
\hline 2 & Length of stem leaves petiole (mm) & 34 & Rostrum length (mm) \\
\hline 3 & Length of stem leaves (mm) & 35 & Style length (mm) \\
\hline 4 & Width of stem leaves (mm) & 36 & Stamen filament length (mm) \\
\hline 5 & Length / width of stem leaves (mm) & 37 & Fruit length (mm) \\
\hline 6 & Width / length of stem leaves (mm) & 38 & Number of flowers per inflorescence \\
\hline 7 & No segment stem leaves (mm) & 39 & Type root \\
\hline 8 & Length of basal leaves petiole (mm) & 40 & Vegetation forms \\
\hline 9 & Length of basal leaves (mm) & 41 & State of stem strength \\
\hline 10 & Width of basal leaves (mm) & 42 & State of stem branches \\
\hline 11 & Length / width of basal leaves (mm) & 43 & Leave shape \\
\hline 12 & Width / length of basal leaves (mm) & 44 & Phyllotaxy \\
\hline 13 & Number of segment basal leaves & 45 & Leaf tips \\
\hline 14 & Calyx length (mm) & 46 & Shape of segments basal leaves \\
\hline 15 & Calyx width (mm) & 47 & Stamen filament colour \\
\hline 16 & Calyx length / width (mm) & 48 & Stigma hair \\
\hline 17 & Petal length (mm) & 49 & Mericarp shape \\
\hline 18 & Petal width (mm) & 50 & Mericarp surface \\
\hline 19 & Petal length / width (mm) & 51 & Mericarp hair \\
\hline 20 & Mericarp length (mm) & 52 & Mericarp Rostrum hair \\
\hline 21 & Mericarp width (mm) & 53 & Sepal hair \\
\hline 22 & Mericarp length / width (mm) & 54 & Sepal hair density \\
\hline 23 & Seed length (mm) & 55 & Peduncle and pedicel hair \\
\hline 24 & Seed width (mm) & 56 & Anthers colour \\
\hline 25 & Seed length / width (mm) & 57 & Stem hair \\
\hline 26 & Stipules length (mm) & 58 & Stem hair density \\
\hline 27 & Stipules width (mm) & 59 & Leaf hair \\
\hline 28 & Stipules length / width (mm) & 60 & Bract shape \\
\hline 29 & Bract length (mm) & 61 & Stipules shape \\
\hline 30 & Bract width (mm) & 62 & Bract and stipules hair density \\
\hline 31 & Bract length / width (mm) & 63 & Bract and stipules hair \\
\hline 32 & Pedicel length (mm) & 64 & Shape of segments cauline leaves \\
\hline
\end{tabular}


Table 2 (continued)

\begin{tabular}{|c|c|c|c|}
\hline No & Character & No & Character \\
\hline 65 & Shape of calyx & 73 & Mericarp colour \\
\hline 66 & Calyx apex & 74 & Seed colour \\
\hline 67 & Petal shape & 75 & Seed shape \\
\hline 68 & State of petal ligule & 76 & Seed surface ornamentation \\
\hline 69 & Shape of petal lobes & 77 & Peduncle and pedicel hair density \\
\hline 70 & State of petal ligule hair & 78 & Petioles hair \\
\hline 71 & Stamen filament hair & 79 & Petioles hair density \\
\hline 72 & Mericarp hair density & 80 & Leaf hair density \\
\hline
\end{tabular}

$7-10 \mathrm{~min}$ at $72{ }^{\circ} \mathrm{C}$. The amplification products were observed by running on $1 \%$ agarose gel, followed by the ethidium bromide staining. The fragment size was estimated by using a $100 \mathrm{bp}$ molecular size ladder (Fermentas, Germany).

\section{Data analyses}

Morphological studies - Morphological characters were first standardised (mean $=0$, variance $=1$ ) and used to establish Euclidean distance among pairs of taxa (Podani 2000). For grouping of the plant specimens, the UPGMA (unweighted paired group using average) and MDS (multidimensional scaling) were used (Podani 2000). PCA (principal components analysis) biplot was used to identify the most variable morphological characters among the studied populations (Podani 2000). PAST version 2.17 (Hammer et al. 2012) was used for multivariate statistical analyses of morphological data.

Molecular analyses - ISSR bands obtained were coded as binary characters (presence $=1$, absence $=0$ ) and used for genetic diversity analysis. Parameter like Nei's gene diversity $(\mathrm{H})$, Shannon information index $(\mathrm{I})$, number of effective alleles, and percentage of polymorphism were determined (Freeland et al. 2011, Weising et al. 2005). Nei's genetic distance among populations was used for neighbour joining (NJ) clustering, while TCS network (Clement et al. 2002) was used for networking by Popart program (http://popart.otago.ac.nz).

Mantel test checked the correlation between geographical and genetic distance of the studied populations (Podani 2000). These analyses were done by PAST ver. 2.17 (Hamer et al. 2012), DARwin ver. 5 (2012) software.

AMOVA (analysis of molecular variance) test (with 1000 permutations) as implemented in GenAlex 6.4 (Peakall and Smouse 2006), was used to show genetic difference of the populations. 
The genetic structure of populations was studied by Bayesian based model STRUCTURE analysis (Pritchard et al. 2000). For STRUCTURE analysis, data were scored as dominant markers (Falush et al. 2007). We used the admixture ancestry model under the correlated allele frequency model. A Markov chain Monte Carlo simulation was run 20 times for each value of $\mathrm{K}$ after a burn-in period of $10^{5}$. The Evanno test was performed on STRUCTURE result to determine proper number of $K$ by using delta $K$ value (Evanno $e t$ al. 2005). Gene flow was determined by (i) calculating $\mathrm{Nm}$ an estimate of gene flow from Gst by PopGene ver. 1.32 (1997) as: Nm = 0.5 (1-Gst)/Gst.

ITS and $r b c \mathrm{~L}$ data of the species studied were obtained from NCBI (The National Centre for Biotechnology Information) and used for further analyses. Accession numbers for species retrieved from GenBank are presented in the Appendix.

ITS and $r b c$ L DNA sequences were first aligned and cured by MUSCLE, and then used for constructing phylogenetic trees and TCS networking. MEGA 7 (2017) was used for drawing phylogenetic trees and Popart program (2017) was used for networking.

Incongruence between ITS and $r b c \mathrm{~L}$ sequences was checked by two different methods. First by performing Mantel test (Podani 2000) as implemented in PAST ver. 5. (2000) program and second by estimating the Robinson-Foulds distance as implemented in PHYLIP ver. 3.69 (2013). We found no difference between ITS and $r b c \mathrm{~L}$ sequences, and therefore phylogenetic tree was constructed based on a combined data set. Two species, namely Geranium purpureum and G. robertianum of the sect. Ruberta were used as outgroup taxa.

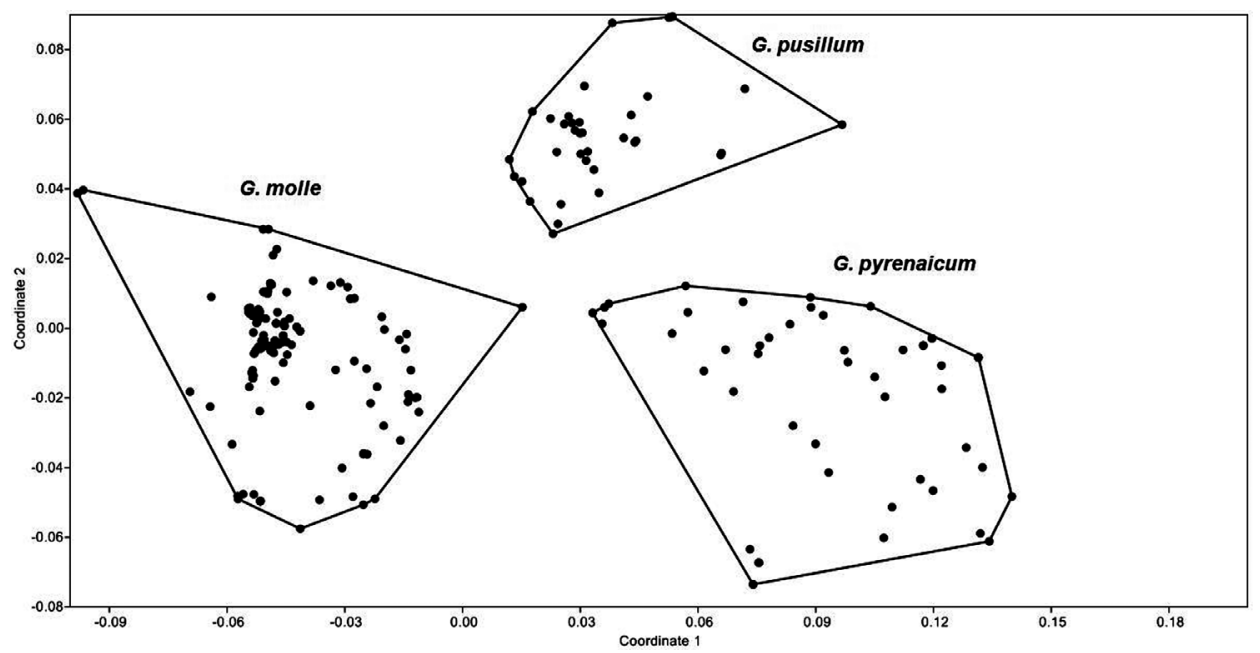

Fig. 2. Multidimentional scaling plot based on both quantitative and qualitative morphological characters delimiting the studied species in sect. Batrachioidea 


\section{RESULTS}

\section{Species delimitation and inter-relationship}

Morphometry - Different clustering and ordination methods produced similar results therefore, only MDS plot of morphological characters are presented here (Fig. 2). In general, plant samples of each species were grouped together and formed a separate group. This result shows that morphological characters studied can delimit Geranium species. In the studied specimens we did not encounter intermediate forms.

PCA analysis of morphological traits revealed that the first three PCA components comprised about $71.5 \%$ of total variation. Morphological characters like, bract width, mericarp surface, mericarp hair, seed shape, sepal hair, positively correlated with these components and are the most variable morphological characters among the studied species and therefore, they may be used in taxonomy of these taxa.

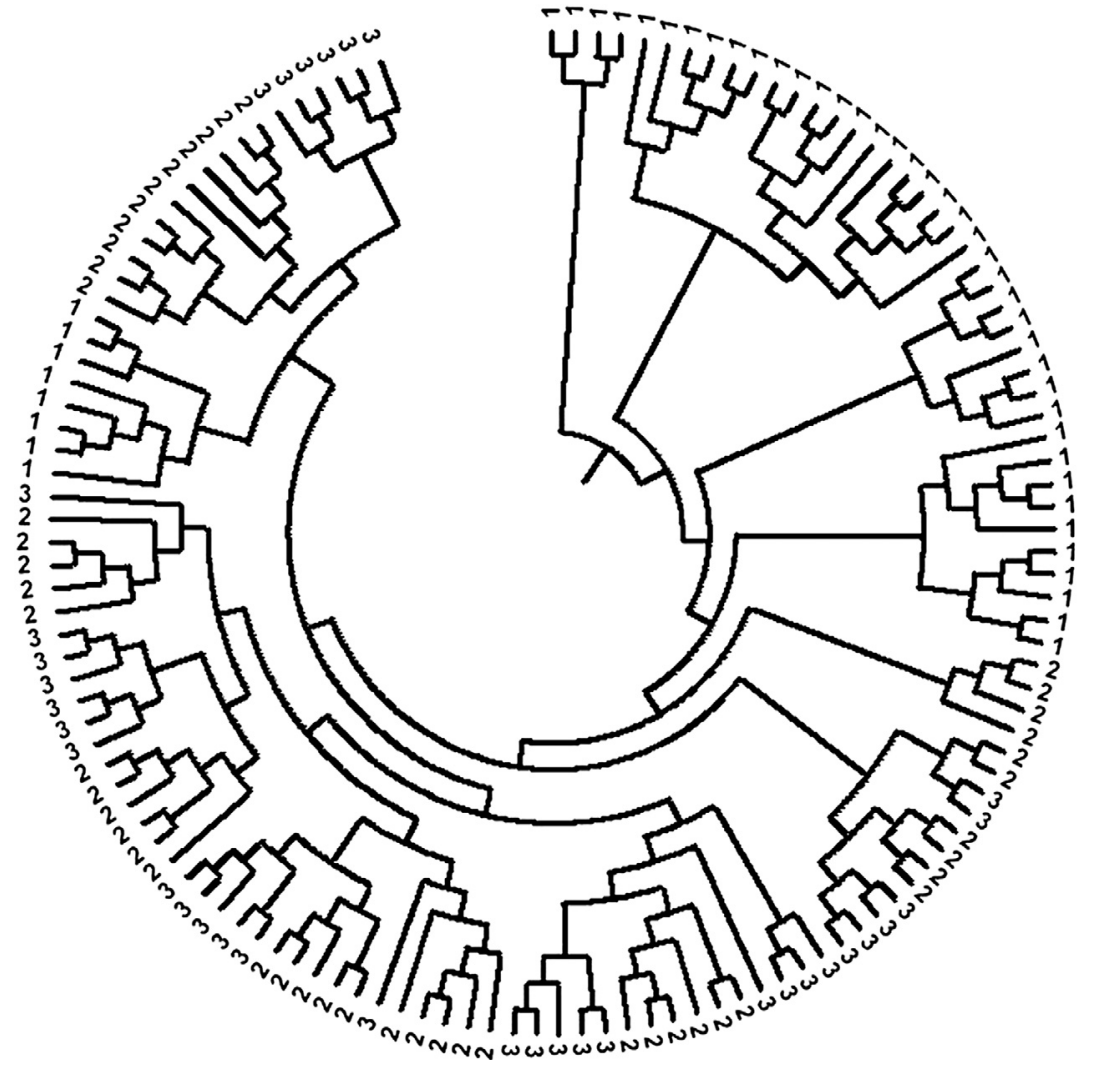

Fig. 3. UPGMA dendrogram of the studied populations based on ISSR markers. Abbreviations: 1-3 are G. molle (1); G. pyrenaicum (2); G. pusillum (3) 
Molecular analysis - UPGMA clustering and TCS networking (Figs 3-4), of the studied populations did not entirely delimit the studied species and revealed that plants in these species are intermixed. In UPGMA circular dendrogram, a higher degree of intermixture occurred between G. pusillum and G. pyrenaicum.

TCS network (Fig. 4) revealed that although species 1 (G. molle) is more distinct than the other two species, but its accessions showed a high degree of intraspecific genetic variability as they are positioned in different places of the network.

Incongruence tests between ITS and $r b c \mathrm{~L}$ sequences by Mantel test and $\mathrm{s}$ estimating the Robinson-Foulds distance revealed no difference between ITS and $r b c \mathrm{~L}$ sequences, and therefore phylogenetic tree was constructed based on a combined data set. The phylogenetic tree separated two outgroup species namely Geranium purpureum and G. robertianum of the sect. Ruberta in a single clade, while the in-group species were distributed in two separate clades.

UPGMA trees of combined data set of ITS and $r b c$ L supported separation of the three species as their accessions formed separate clusters with high bootstrap value (>0.98) (Fig. 5). In general UPGMA trees of cp-DNA and ITS

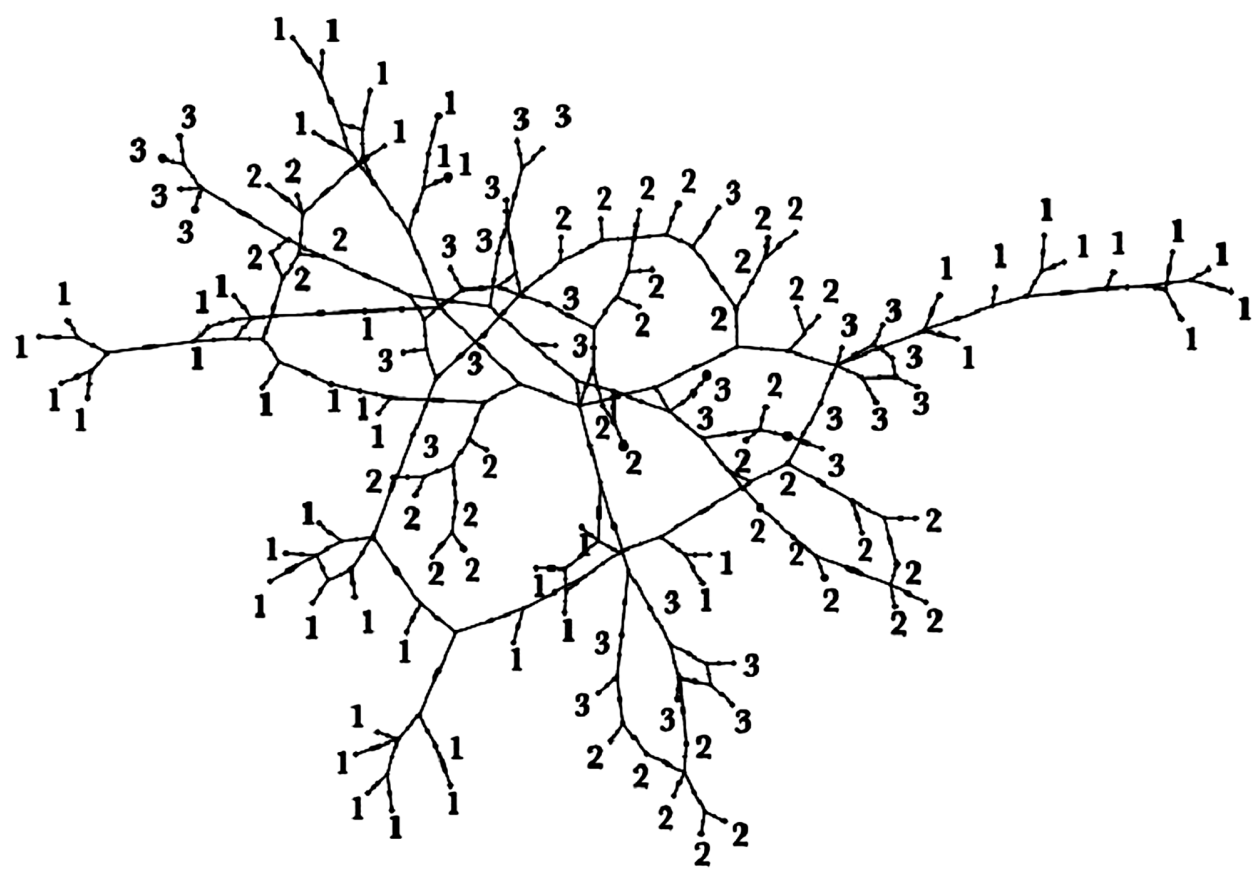

Fig. 4. TCS network of the studied populations based on ISSR markers. Abbreviations: 1-3 are G. molle (1); G. pyrenaicum (2); G. pusillum (3) 


\section{Table 3}

Genetic diversity parameters based on ISSR data in the studied Geranium species $(\mathrm{N}=$ number of samples, $\mathrm{Na}=$ number of different alleles, $\mathrm{Ne}=$ number of effective alleles, $\mathrm{I}=$ Shannon's information index, $\mathrm{He}=$ gene diversity, $\mathrm{UHe}=$ unbiased gene diversity, $\mathrm{P} \%=$ percentage of polymorphism, populations)

\begin{tabular}{lrrrcccc}
\hline Species & $\mathrm{N}$ & $\mathrm{Na}$ & $\mathrm{Ne}$ & $\mathrm{I}$ & $\mathrm{He}$ & $\mathrm{UHe}$ & $\mathrm{P} \%$ \\
\hline G. molle & 132.000 & 1.935 & 1.348 & 0.364 & 0.226 & 0.227 & 96.74 \\
G. pyrenaicum & 49.000 & 1.402 & 1.236 & 0.243 & 0.150 & 0.151 & 69.57 \\
G. pusillum & 35.000 & 1.250 & 1.234 & 0.233 & 0.146 & 0.148 & 61.96 \\
\hline
\end{tabular}

trees is in agreement with morphology data. It showed affinity between $G$. pusillum and G. pyrenaicum. It also separated G. molle from the other species.

\section{Population genetic analysis (ISSR)}

Genetic diversity parameters determined in three studied species (Table 3) revealed that G. molle had the highest level of genetic polymorphism $(96.74 \%)$, while the lowest level of the same occurred in G. pusillum (61.96\%). In general these species have moderate to high degree of genetic variability which may be due to cross-pollination mode of reproduction in these plants.

The AMOVA test did not produce significant molecular differences $(\mathrm{P}=$ $0.07)$ among the studied species. This is in agreement with high $\mathrm{Nm}$ value $(\mathrm{Nm}=11.64)$ and gene flow obtained in them. AMOVA revealed that $8 \%$ of total genetic variability occurred among the studied populations while $92 \%$ occurred within these species.

Nei's genetic identity and the genetic distance determined among the studied species are presented in Table 4 . The results showed that the highest

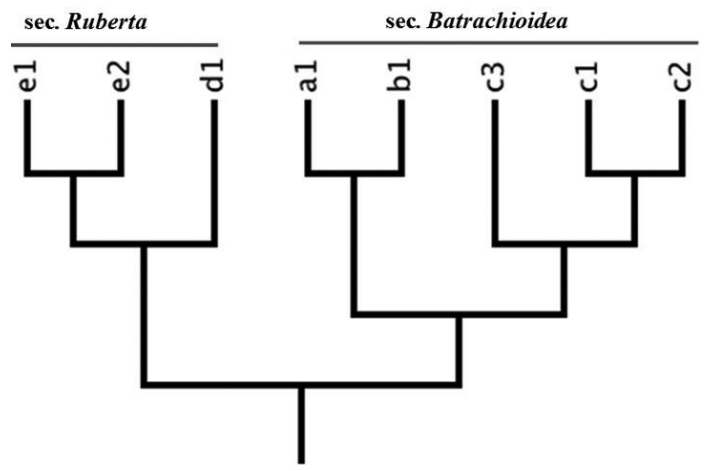

Fig. 5. Phylogenetic tree of the species studied based on combined ITS and $r b c \mathrm{~L}$ sequences. Species abbreviations: $\mathrm{a} 1=$ G. pyrenaicum; $\mathrm{b} 1=$ G. pusillum; $\mathrm{c} 1-\mathrm{c} 3=$ G. molle; $\mathrm{d} 1=$ G. purpureum; $\mathrm{e} 1-\mathrm{e} 2=\mathrm{G}$. robertianum 
Table 4

Nei's genetic identity (above diagonal) and genetic distance (below diagonal) among the study population ID $(1=G$. molle, $2=$ G. pyrenaicum, $3=G$. pusillum $)$

\begin{tabular}{cccc}
\hline Population ID & 1 & 2 & 3 \\
\hline 1 & - & 0.9821 & 0.9850 \\
2 & 0.0181 & - & 0.9941 \\
3 & 0.0151 & 0.0059 & - \\
\hline
\end{tabular}

degree of genetic similarity (0.99) occurred between G. pusillum and G. pyrenaicum and then between G. molle and G. pusillum, G. pyrenaicum (0.985). As we did not encounter any intermediate plants particularly in the areas of overlap, we consider these species to have high degree of ancestral shared alleles.

Mantel test did not produce significant correlation $(r=0.01, p=0.73)$ between geographical distance and genetic distance of these species and therefore, no isolation by distance (IBD) exists between them.

STRUCTURE analysis followed by Evanno test also produced delta $\mathrm{K}=$ 2. Therefore, we do have at least 2 genetic groups in the studied species: 1) - specimens with green and red segments. These are accessions of Geranium molle; and 2) - specimens having green coloured segments as dominant colour. These are accessions of G. pyrenaicum and G. pusillum. Admixture ancestry model used in STRUCTURE revealed genetic affinity between G. pyrenaicum and G. pusillum, due to shared common alleles (Fig. 6). This is in agreement with TCS network presented before.

Populations of Geranium molle revealed two types of coloured segments, 1) - mostly green (similar to the other two studied species, e.g. populations $1,3,6,12-14,17-18)$, and 2) - mostly red coloured segments. This is in agreement with UPGMA circular dendrogram presented before that revealed within species genetic variability among populations. As stated before we did not

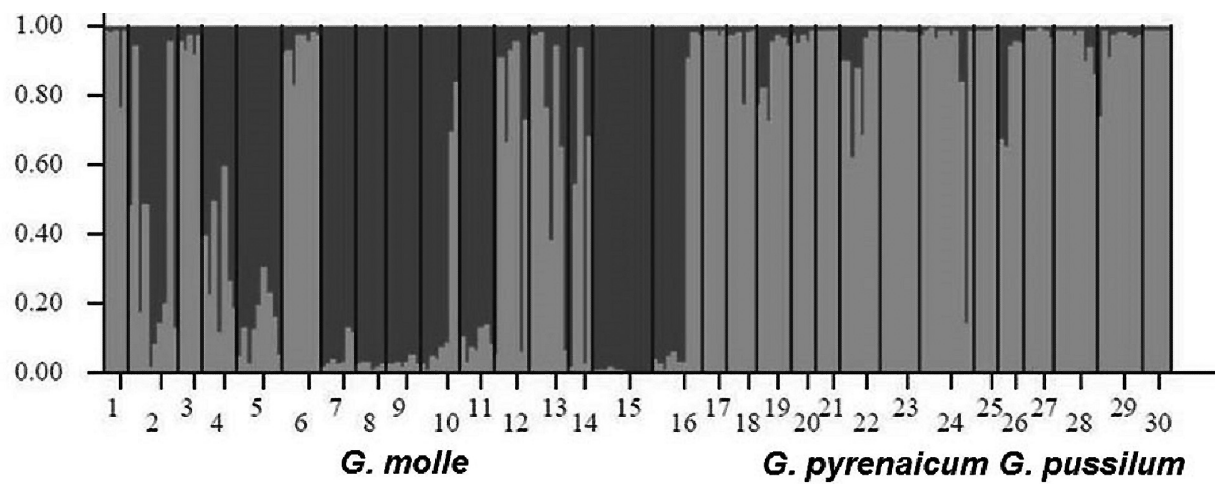

Fig. 6. STRUCTURE plot of Geranium species showing interspecific genetic variability and admixture 
encounter plants with intermediate morphological characters or combination of characters from two species, therefore, we may suggest that these plants may differ in their genetic content possibly due to local adaptation. The genetic variability observed did not affect morphological characters of the plants and all were identified as G. molle.

\section{DISCUSSION}

\section{Species delimitation and taxonomic consideration}

The species delimitation in complex groups and in those that the species have different degree of morphological overlap is a tedious and difficult task. In these situations, it is suggested to use different and combined approaches like morphological, molecular, cytological, etc. to determine the species boundaries (Carstens et al. 2013). In the last few decades the use of molecular markers as tools for species and subspecies delimitation has drastically increased (Sheidai et al. 2013, 2016). The basic premise for the use of molecular markers for species delimitation is that the "species tree" should be inferred from a "gene tree".

The sect. Batrachioidea is known to have interspecific hybrids (Van Loon 1984c). Successful interspecific cross was obtained between Geranium molle and G. brutium. Some of the previously identified interspecific hybrids were latter on considered not to be hybrid. For example, according to (Aedo et al. 1998b) Geranium luganense, G. oenense and G. hybridum are probably not hybrid, but are the synonyms of Geranium molle (the first two) or G. pusillum.

The present study did not identify intermediate plants in either of $G$. pusillum and G. molle.

Aedo et al. (1998b) suggested that sect. Divaricata and Batrachioidea could constitute a monophyletic group, and that the taxonomic problems on sect. Batrachioidea is due to morphological overlaps in two species, i.e. G. pyrenaicum and G. molle.

Variability within the species in sect. Batrachioidea is the source of morphological complexity, as evidenced in G. pyrenaicum (Ortiz 1989). The present study revealed these species may be delimited by morphological characters as well as combination of ITS and $r b c \mathrm{~L}$ sequences. The species relationship obtained also is in agreement with morphological analysis and supports taxonomic treatment of Flora Iranica (Schönbeck-Temesy 1970).

PCA analysis suggests that characters like bract width, mericarp surface, mericarp hair, seed shape, sepal hair, length and width of mericarp, seed length, shape of petal lobes, length and width of corolla, and length and width of leaves may be used in species delimitation. 
Interspecific morphological and genetic variability

Population genetic study provides valuable information about genetic structure of plants, the stratification versus gene flow among the species populations, genetic divergence of the populations, etc. (Sheidai et al. 2016). These information have different applications, and from like pure understanding of biology of the species to conservation of endangered species, choosing of proper parents for hybridisation and breeding and phylogeography and mechanism of invasion (Freeland et al. 2011). Geranium pyrenaicum is widespread in our country and it has several medicinal applications (Baytop 1999), however, we had no information on its population genetic structure. The present study revealed the presence of high degree of genetic variability within this species which is highly correlated with its reproductive mode. According to Philipp (1985), most perennial species of Geranium produce large and protandrous flowers, while a slight or null protandry is accompanied by an increased selfing and a reduction in flower size.

Acknowledgement - The authors thank anonymous reviewers for valuable comments on an earlier draft.

\section{REFERENCES}

Aedo, C. (1996): Revision of Geranium subgenus Erodioidea (Geraniaceae). - Syst. Bot. Monogr. 49: 1-104. https://doi.org/10.2307/25027866

Aedo, C. F., Garmendia, M. and Pando, F. (1998a): World checklist of Geranium L. (Geraniaceae). - Anales Jard. Bot. Madrid 56: 211-252. https://doi.org/10.3989/ajbm.1998.v56. i2.230

Aedo, C., Aldasoro, J. J. and Navarro, C. (1998b): Taxonomic revision of Geranium L., sections Divaricata Rouy and Batrachioidea W. D. J. Koch (Geraniaceae). - Ann. Mo. Bot. Gard. 85: 594-630. https://doi.org/10.2307/2992018

Baytop, T. (1999): Therapy with medicinal plants in Turkey (past and present). 2nd ed. - Nobel Tip Kitabevleri Ltd., Istanbul, 334 pp.

Carstens, B. C., Pelletier, T. A., Reid, N. M. and Satler, J. D. (2013): How to fail at species delimitation. - Mol. Ecol. 22: 4369-4383. https://doi.org/10.1111/mec.12413

Clement, M., Snell, Q., Walke, P., Posada, D. and Crandall, K. (2002): TCS: estimating gene genealogies. - Proc 16th Int Parallel Distrib Process Symp 2: 184.

Davis, P. H. (1965): Geraniaceae. - In: Davis, P. H. (ed.): Flora of Turkey and East Aegean Islands. Vol. 2, pp. 450-488.

Evanno, G., Regnaut, S. and Goudet, J. (2005): Detecting the number of clusters of individuals using the software STRUCTURE: a simulation study. - Mol. Ecol. 14: 2611-2620. https://doi.org/10.1111/j.1365-294x.2005.02553.x 
Falush, D., Stephens, M. and Pritchard, J. K. (2007): Inference of population structure using multilocus genotype data: dominant markers and null alleles. - Mol. Ecol. Notes 7: 574-578. https://doi.org/10.1111/j.1471-8286.2007.01758.x

Freeland, J. R., Kirk, H. and Peterson, S. D. (2011): Molecular ecology. 2nd ed. - Wiley-Blackwell, UK, 449 pp.

Hammer, Ø., Harper, D. A. T. and Ryan, P. D. (2012): PAST: paleontological statistics software package for education and data analysis. - Palaeont. Electr. 4: 9.

Janighorban, M. (2009): Flora of Iran. Vol. 62. Geraniaceae. - The Research Institute of Forests and Rangelands. (in Persian)

Koohdar, F., Sheidai, M., Talebi, S. Y. and Noormohammadi, Z. (2015): Population genetic structure in medicinal plant Lallemantia iberica (Lamiaceae). - Biodiversitas 16: 139_ 144. https://doi.org/10.13057/biodiv/d160206

Minaeifar, A., Sheidai, M., Attar, F., Noormohammadi, Z. and Ghasemzadeh-Baraki, S. (2016): Biosystematic study in the genus Cousinia Cass. (Asteraceae), section Cousinia. - Bio. Syst. Ecol. 69: 252-260. https://doi.org/10.1016/j.bse.2016.10.008

Mosaferi, S., Sheidai, M., Keshavarzi, M. and Noormohammadi, Z. (2016): Species delimitation and population structure analysis in Polygonum species (section Polygonum). - Wulfenia 23: 98-112.

Mosaferi, S., Sheidai, M., Keshavarzi, M. and Noormohammadai, Z. (2015): Genetic diversity and morphological variability in Polygonum aviculare s.l. (Polygonaceae) of Iran. - Phytotaxa 233: 166-178. https://doi.org/10.11646/phytotaxa.233.2.4

Ortiz, S. (1989): Caracterizacion taxonomica de las poblaciones iberico-occidentales de Geranium pyrenaicum Burm. fil. (Geraniaceae). - Anales Jard. Bot. Madrid 47: 242-244.

Peakall, R. and Smouse, P. E. (2006): GENALEX 6: genetic analysis in Excel. Population genetic software for teaching and research. - Mol. Ecol. Notes 6: 288-295. https://doi. org/10.1111/j.1471-8286.2005.01155.x

Philipp, M. (1985): Reproductive biology of Geranium sessiliflorum, 1. Flower and flowering biology. - New Zeal. J. Bot. 23: 567-580. https://doi.org/10.1080/002882 5x.1985.10434228

Podani, J. (2000): Introduction to the exploration of multivariate data. - Backhuys Publisher, Leiden, 407 pp.

Pritchard, J. K., Stephens, M. and Donnelly, P. (2000): Inference of population structure using multilocus genotype data. - Genetics 155: 945-959.

Safaei, M., Sheidai, M., Alijanpoor, B. and Noormohammadi, Z. (2016): Species delimitation and genetic diversity analysis in Salvia with the use of ISSR molecular markers. - Acta Bot. Croat. 75: 45-52. https://doi.org/10.1515/botcro-2016-0005

Schönbeck-Temesy, E. (1970): Geraniaceae. - In: Rechinger, K. H. (ed.): Flora Iranica. Vol 69. Akademische Druck, Graz, Austria, pp. 30-58.

Sheidai, M., Ahmad-Khanbeygi, M. and Attar, F. (2012): New chromosome number reports in Cousinia species (Compositae). - Cytologia 77: 11-16. https://doi.org/10.1508/cytologia.77.11

Sheidai, M., Naji, M., Noormohammadi, Z., Nouroozi, M. and Ghasemzadeh-Baraki, S. (2016): Contemporary inter-specific hybridization between Circium aduncum and C. haussknechtii (Asteraceae): Evidence from molecular and morphological data. Genetika 48: 497-514. https://doi.org/10.2298/gensr1602497s

Sheidai, M., Zanganeh, S., Haji-Ramezanali, R., Nouroozi, M., Noormohammadi, Z. and Ghasemzadeh-Baraki, S. (2013): Genetic diversity and population structure in four 
Cirsium (Asteraceae) species. - Biológia 68: 384-397. https://doi.org/10.2478/s11756013-0162-x

Van Loon, J. C. (1984): Hybridization experiments in Geranium. - Genetica 65: 167-171. https://doi.org/10.1007/bf00135281

Weising, K., Nybom, H., Wolff, K. and Kahl, G. (2005): DNA fingerprinting in plants. Principles, methods, and applications. 2nd ed. - CRC Press, Boca Rayton, 472 pp.

Yeo, P. F. (1987): Fruit-discharge-type in Geranium (Geraniaceae): its use in classification and its evolutionary implications. - Bot. J. Linn. Soc. 89: 1-36. https://doi. org/10.1111/j.1095-8339.1984.tb00998.x

Zohary, M. (1972): Flora Palaestina. Platanaceae to Umbelliferae. - The Israel Academy of Sciences and Humanities, Jerusalem, Israel.

\section{APPENDIX}

GenBank accession numbers for nrDNA ITS and cpDNA $r b c \mathrm{~L}$ sequence data, and voucher information with herbarium where specimen is deposited. Geranium pyrenaicum - HE795061.1 (Palazzesi et al. 2012), KJ204349.1 (Wyler and Litman 2015)

Geranium pusillum - DQ525070.1 (Fiz-Palacios and Aldasoro 2008), JX913454.1 (Park et al. 2017)

Geranium molle - KX167627.1 (de Vere and Ford 2016), JQ412370.1 (Bezeng et al. 2013)

Geranium purpureum - KX167629.1 (de Vere 2016), JN893649.1 (de Vere et al. 2012)

Geranium robertianum - AB689056.1 (Nishida and Azuma 2012), HQ590118.1 (Burgess et al. 2016) 